\title{
A Control Scheme for Current with Cancellation of Back EMF and Tracing Fault Adapted Commutation Shift for SRM Drive
}

\author{
V. Jayalakshmi, Rathika. R, S. Prakash,
}

\begin{abstract}
In our research, the winding current is improved for the switched reluctance motor for the purpose of control scheme and efficient accleration. The proposed system of DCSC, the phase with errors are extracted with raising winding current, these are processed for generating shifting angle with enhanced commutation and hence the improved winding current can be achieved under operating range. The improvement in current gradually improved by augmenting the CFBC also experimentally DCSC is verified. The designing of robust speed controlling scheme is achieved by the parameters of good acceleration and deceleration with certain dynamic characteristics and reversible running parameters.
\end{abstract}

Key words-speed control, switched-reluctance motor, current control, electromotive force, commutation tuning.

\section{INTRODUCTION}

CURRENT-CONTROL SCHEME for the Switched Reluctance motor which is simply called (SRM) which has some of the structural features and parameters, in order to develop high torque capability. The high potential applications such that electrically designed hybrid vehicles, generators, cooling fans, motors. The switching control with suitable power converter in SRM driver is to establish with existing converters. [25],[27],[29]

The converters with asymmetric bridge converters consist of controlling ability with Pulse width Modulation switching. The high performance of dynamic controlled SRM drive initial step is done. The parameter such as current control with constant switching frequency, peak current control, hysteresis control with adaptive sliding currentcontrol system approaches has been designed.. The calculated reference voltage estimates the magnetizing curves in motor. The inductance of motor is determined on the predicted required voltage for PWM duty ratio. Also the fixed switching frequency predictive control of current is utilized in duty ratio. The entire performance with its major drawbacks compared to the hysteresis control . [1],[3],[5]

In this paper, current controller with fixed frequency changing is presented. The equivalent model of the circuit

Revised Manuscript Received on August 22, 2019.

V.Jayalakshmi Associate Professor Department of EEE,Bharath Institute of Higher Education \& Research,TamilNAdu

Rathika. R, Assistant Professor Department of EEE,Bharath Institute of Higher Education \& Research,TamilNAdu

S.Prakash, Professor Department of EEE,Bharath Institute of Higher Education \& Research,TamilNAdu with using SRM consists of magnetic saturation and with mutual coupling. Here the model predictive current control with estimation of inductance approach is presented. The following model had its own benefit with constant changing frequency and low ripple current..

For the speed control methods includes a) adaptive control b) fuzzy control c) robust control and sliding mode controls. The known parameters of winding current tracking waveform and the torque of SRM must be properly set with respect to the given load and speed. On considering about turn-on angle, turn off angle combination for SRM driver has been developed to pursued performance of the maximum torque. This includes torque ripple, maximum torque, minimum vibration these leads to increase in winding current time and low inductance area. [19],[21],[23]

As to develop DCSC we have to consider errors while tracking phase winding, stable commutation shift angle automatically. In order to have current control with robust speed control is applied to achieve the regulation response and speed tracking experimentally verified and the performance is achieved. [8],[ 10],[12]

\section{SRM DRIVE-REALIZATION}

\section{A. FACTS OBSERVED}

Facts consider for observation:

Consider the factors back-EMF on inductance slope is dependent with current and rotor speed associated with it. Depending on the developed torque and winding current response the performance will be either under high speed or with high load. In order to improve the winding current the equivalent commutation field is employed.

SRM drives high acceleration ability since torque is proportional to the square of the current. The drive can be operated as motor or generator.

By reversing the commutation sequence i.e., the armature winding excitation the SRM driver will runs in reverse direction.

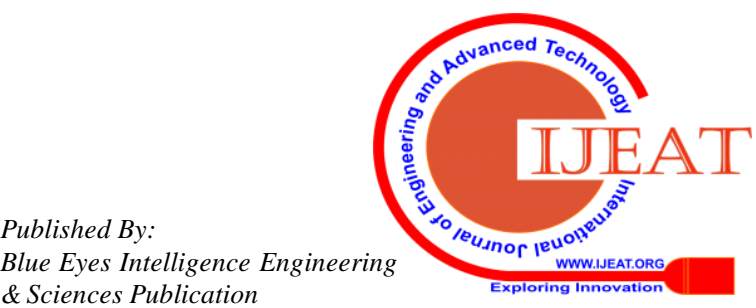




\section{B. Configuration of the System}

The SRM motor driver system mainly consists of a following:

The control scheme is described in dig. The scheme proposed the structure of phase current control scheme. The proposed SRM is rated as three-phase with $1500 \mathrm{rpm}, 1.5 \mathrm{~kW}$. The frequency ranges about $200 \mathrm{~Hz}$ which is measured in the three-phase winding inductance using LCR meter. Here we observed the unbalanced three-phase winding inductances; this effect can be eliminated by the dynamic responses of current and speed. The diagram shows the SRM asymmetric bridge converter.

\section{CIRCUIT DIAGRAM:}

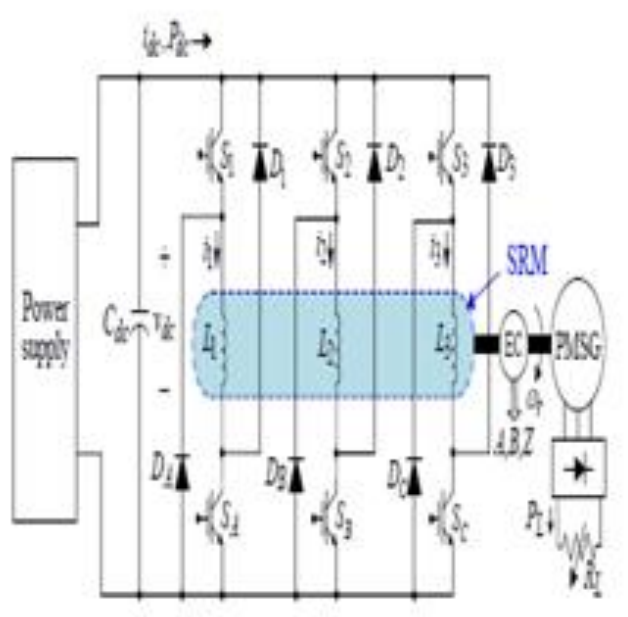

Figure 1.: Circuit Diagram

\section{PROPOSED CONTROL SCHEMES}

\section{A. Current Control}

The schematic description of current control scheme is shown in the fig. which consists of the following.

a) Current feedback controller (CFBC)

b) Back-EMF

\section{B. Dynamic Commutation Shift Controller}

The proposed configuration describes about the dynamic commutation shift controller with the defined parametric variables. [2 ],[ 4],[6]

(a) Methodology and control scheme

The main objective of the DCSC is to produce the various speed and loads automatically with advancing commutation shift angle possesses relevant to the field-weakening to reduce the back-EMF. Thereby improvement in torque, current and performance in speed. The proposed concept denotes the advanced commutation shifting. The errors in the rising winding current of all phases are extracted by multiplying the commutation signal. The summation of the total error is determined by the adding all error signals. The average values are obtained by the low-pass filter. This filter is utilized in such a way that in order to reduce the chattering obtained due to the system noise. Thus finally to obtain suitable commutation shift angle it is regulated by a PI-type controller. [7],[ 9] ,[11]

\section{(b) Performance measures}

The performance of the entire system is based on the given load, speed and the given square wave current tracking errors this will be increased to average torque developed and ripple torque.

There are some of the features in DCSC:

i. Here by minimum inductance region is described in fig. The winding current initially raised and faster due to the effect of zero back-EMF. The regulation of the winding current tracked through the PI controller to yield suitable dynamic shift angle.

ii. The reduction in the winding current tracking error is regulated linearly and stably in constant winding inductance region.. In some cases it's impossible to yield the ideal square-wave winding current. The shortened current tail appears in the slope region of the negative winding inductance and the improved square-wave winding current tracking enhances the average developed torque in the connected motor and hence the related efficiency is achieved in the entire system.

iii. Along with the method rising errors can be minimize.

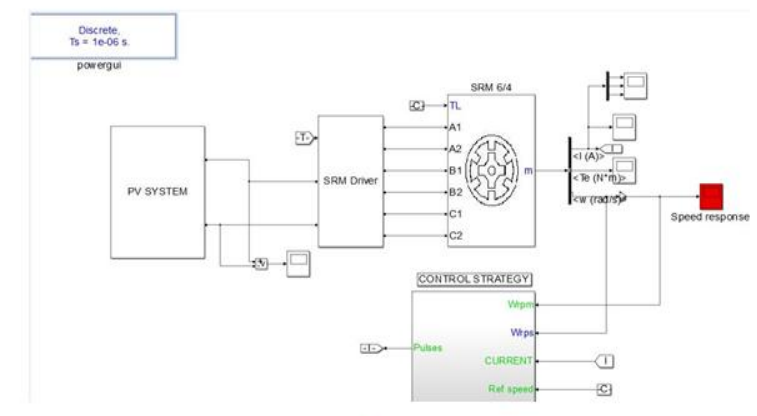

Figure (b): Block Diagram

Figure 2: Block Diagram

\section{PV SYSTEM WITH MPPT CONTROLLER:}

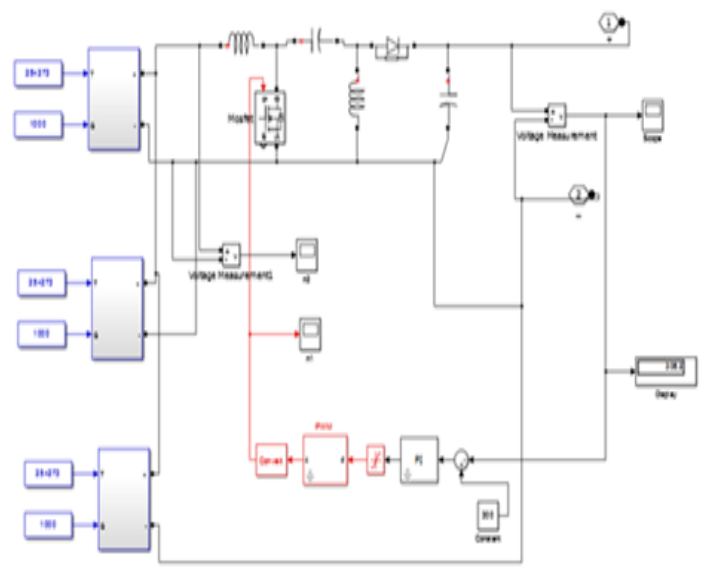

Figure 3: PV system with MPPT Controller 


\section{PV MODEL SYSTEM 1:}

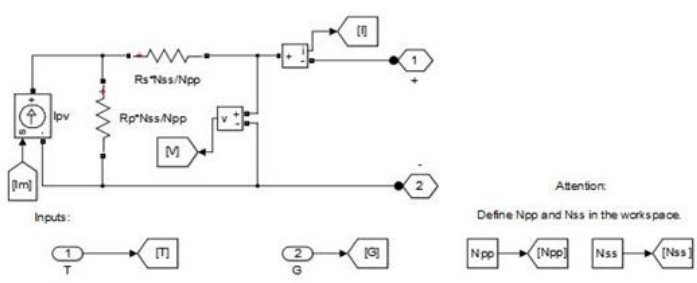

Fig 4:pv model system 1

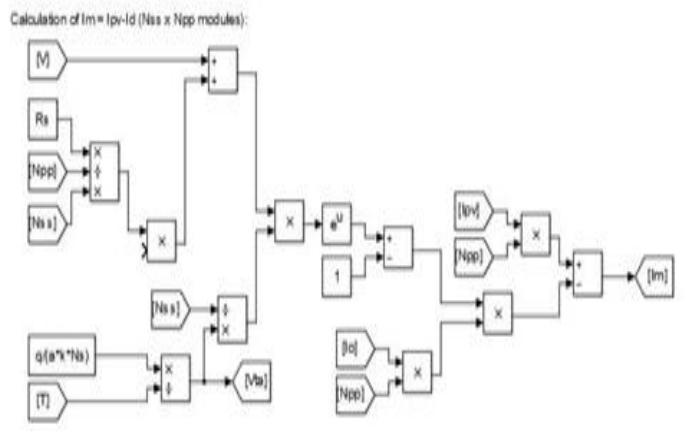

Figure: PV Model System 2

Fig 4:pv model system 2

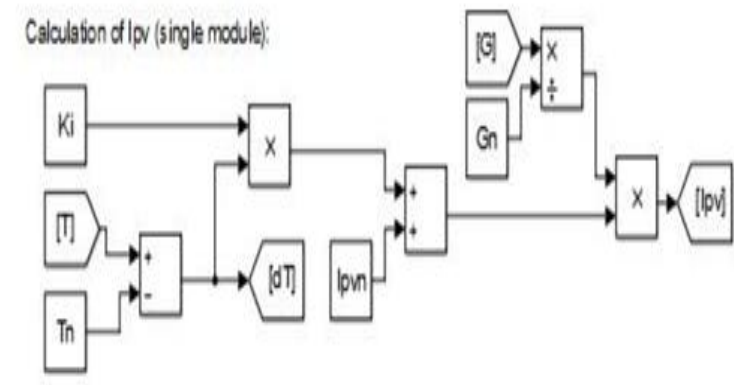

Figure 6: PV Model System3

1

Caladision oflb (ingle nodifi)

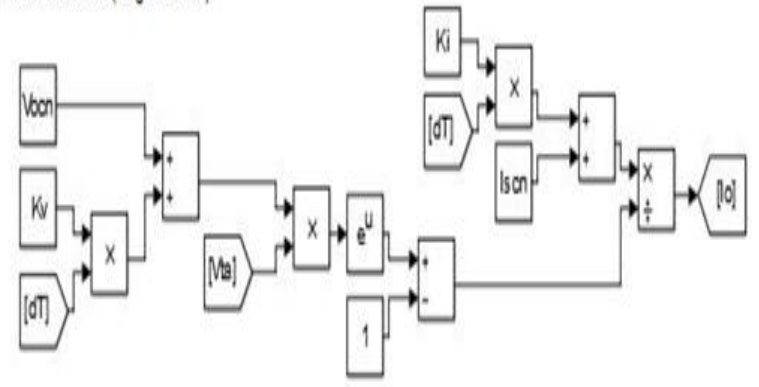

Figure 7:PV Model System4

Fig 5:pv model system 3,4
Our proposed system has been designed and developed in MATLAB and hence the simulation of the system is successfully verified

\section{RESULT AND DISCUSSION}

The following images are the outcome of the simulation work done using MATLAB - Simulink tool.

In our proposed design the motor speed control by using the PIC controller here the back-EMF is reduced with the forward feedback controller. The motor phase is observed for the former motor phase the winding inductance parameters are measured i.e., control signals from feedforward controller is measured. Our system has the winding control scheme to calibrate the driving good characterises such that acceleration of motor reverse running characteristics and deceleration also static and dynamic period responses have be confirmed by our proposed system experimentally.

\section{SPEED IN RPM:}

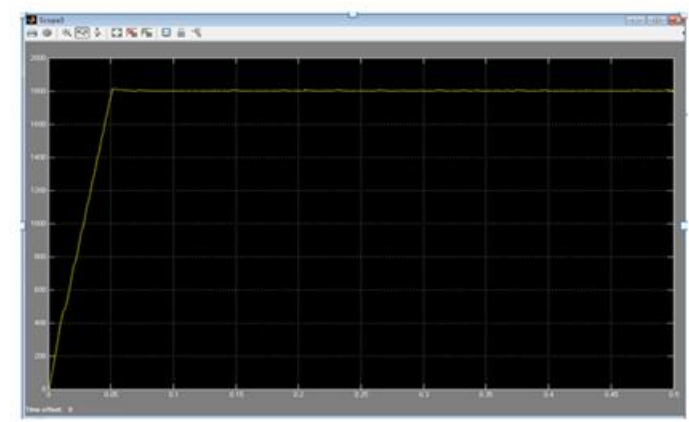

Figure (6): Speed of the motor (RPM) MOTOR CURRENT:

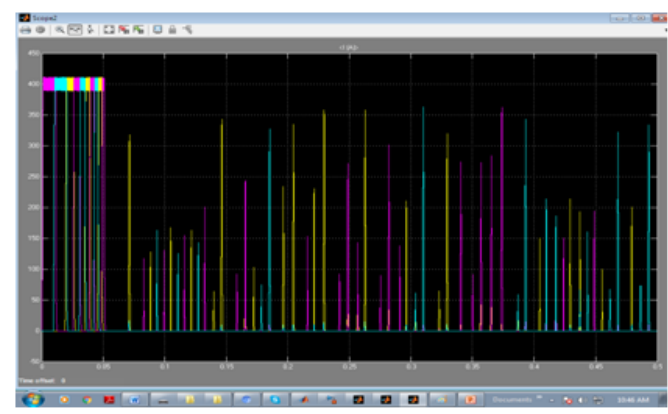

\section{MOTOR TORQUE}

Figure 7: Motor Current

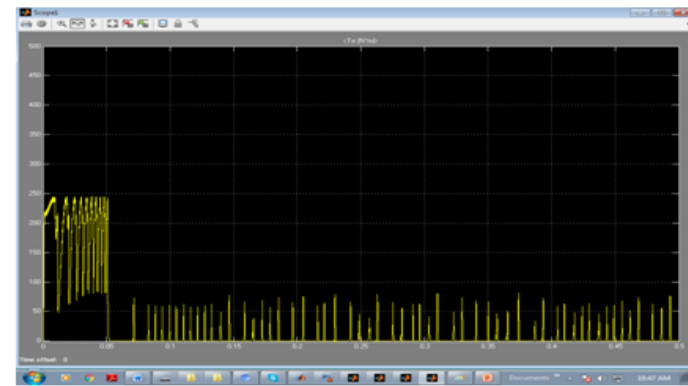

figure 8: Motor Torque 


\section{CONCLUSION}

The Research development of the PIC based SRM drive control system has been presented, in our first phase research the development of PIC based feedback controller has been designed and simulated. Hence the proposed system shows the enhanced result of speed control and the reduction in back-EMF our research is feasible in order to minimize the errors tracked in winding. This proposed structural feature has the high potential applications such that used in hybrid system which has the multiple loads with energy management system. For the further future applications such as cooling fans, home appliances and in power plant can be used with high performance output. Thus our system has ability to provide stable and increased efficient result.

\section{REFERENCES}

1. Sharma, R.K., Irusapparajan, G. \& Periyaazhagar, D. 2019, "Three-phase symmetric cascading Z-source seven levels multilevel inverter excited by multi carrier sinusoidal pulse width modulation scheme", International Journal of Innovative Technology and Exploring Engineering, vol. 8, no. 10, pp. 4269-4274.

2. Velavan, R., Bharanidharan, S. \& Sheeba, B. 2019, "EMF pollution Causes, effects and protection", International Journal of Innovative Technology and Exploring Engineering, vol. 8, no. 9 Special Issue 3, pp. 1166-1168.

3. Saravana, S., Balaji, S., Arulselvi, S. \& John Paul Praveen, A. 2019, "Reliable power quality monitoring and protection system", International Journal of Innovative Technology and Exploring Engineering, vol. 8, no. 9 Special Issue 3, pp. 644-645.

4. Tamil Selvan, S. \& Sundararajan, M. 2019, "Performance Parameters of 3 Value 8t Cntfet Based Sram Cell Design Using H-Spice", International Journal of Recent Technology and Engineering, vol. 8, no. 2 Special issue 5, pp. 22-27.

5. Jac Fredo, A.R., Abilash, R.S., Femi, R., Mythili, A. \& Kumar, C.S. 2019, "Classification of damages in composite images using Zernike moments and support vector machines", Composites Part B: Engineering, vol. 168, pp. 77-86.

6. Kathiravan, P. \& Govindaraju, C. 2019, "Design and evaluation of ultra gain isolated DC-DC converter for photovoltaic system", International Journal of Engineering and Advanced Technology, vol. 8, no. 5, pp 2646-2651.

7. Kripa, N., Vasuki, R. \& Kishore Kanna, R. 2019, "Realtime neural interface controlled au-pair BIMA bot", International Journal of Recent Technology and Engineering, vol. 8, no. 1, pp. 992-994.

8. Mohanraj, Meenaa Kumari, M., Philomina, S. \& Jasmin, M. 2019, "In-situ humidity measurement of hydrogen fuel cell car using MEMS sensor", International Journal of Recent Technology and Engineering, vol. 8, no. 1, pp. 41-43.

9. Velmurugan, T. \& Prakash, S. 2019, "Artificial intelligent based distribution automation of swift fault detection isolation and power restoration for HT network", International Journal of Innovative Technology and Exploring Engineering, vol. 8, no. 6, pp. 1-6.

10. Dwarakesh, K. \& Prem Kumar, G. 2019, "Five-level inverter based sequential boost system using fuzzy logic controller", International Journal of Innovative Technology and Exploring Engineering, vol. 8, no. 6, pp. 12-19.

11. Anne Gifta, A. \& Hemavathi, G. 2019, "Analysis of grid tied solar PV system using ANFIS Algorithm", International Journal of Innovative Technology and Exploring Engineering, vol. 8, no. 6, pp. 312-316.

12. Jayavel, R., Rangaswamy, T.R. \& Prakash, S. 2019, "Efficient grid management system with renewable and conventional power sources", International Journal of Innovative Technology and Exploring Engineering, vol. 8, no. 6, pp. 287-289.

13. Hemavathi, G. \& Maheshwaran, S. 2019, "Proportional resonant controlled high gain step-up converter system with improved response", International Journal of Innovative Technology and Exploring Engineering, vol. 8, no. 6, pp. 317-323.

14. Periyaazhagar, D. \& Irusapparajan, G. 2019, "Design and completion of asymmetric single phase 27 level cascaded mli for various pwm scheme", International Journal of Innovative Technology and Exploring Engineering, vol. 8, no. 6, pp. 792-797.

15. Mahalakshmi, V. \& Vijayaragavan, S.P. 2019, "PV based power electronic converters for high voltage DC applications", International
Journal of Recent Technology and Engineering, vol. 7, no. 6, pp. 670-674.

16. Irusapparajan, G., Periyaazhagar, D., Prabaharan, N. \& Rini Ann Jerin, A. 2019, "Experimental verification of trinary DC source cascaded h-bridge multilevel inverter using unipolar pulse width modulation", Automatika, vol. 60, no. 1, pp. 19-27.

17. Sangeetha, G., Sherine, S., Arputharaju, K. \& Prakash, S. 2019, "On Line Monitoring of Higher Rated Alternator using Automated Generator Capability Curve Administer", Proceedings of the IEEE International Conference on \&amp;quot;Recent Trends in Electrical, Control and Communication\&amp;quot; RTECC 2018, pp. 176.

18. Bycil, V.J. \& Wiselin, M.C.J. 2019, "Modeling and analysis of vibration energy harvesting system using piezo stack", International Journal of Mechanical and Production Engineering Research and Development, vol. 9, no. Special Issue 1, pp. 523-533.

19. Sripada, A., Warrier, A., Kapoor, A., Gaur, H. \& Hemalatha, B. 2018, "Dynamic lateral balance of humanoid robots on unstable surfaces", International Conference on Electrical, Electronics, Communication Computer Technologies and Optimization Techniques, ICEECCOT 2017, pp. 539.

20. Srinivasan, S., Thirumalaivasan, K. \& Sivakumaran, T.S. 2018, "Performance evaluation of double-output luo converters", Journal of Advanced Research in Dynamical and Control Systems, vol. 10, no. 10 Special Issue, pp. 870-878.

21. Karthikayen, A. \& Selvakumar Raja, S. 2018, "A skellam distribution inspired trust factor-based selfish node detection technique in MANETs", Journal of Advanced Research in Dynamical and Control Systems, vol. 10, no. 13, pp. 940-949.

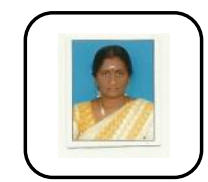

\section{AUTHORS PROFILE}

V.Jayalakshmi Associate Professor Department of EEE,Bharath Institute of Higher Education \& Research,TamilNAdu

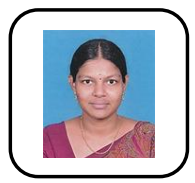

Rathika. R, Assistant Professor Department of EEE,Bharath Institute of Higher Education \& Research,TamilNAdu

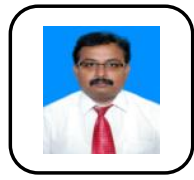

S.Prakash, Professor Department of EEE,Bharath Institute of Higher Education \& Research,TamilNAdu 